\title{
A Modified Free Gingival Graft Technique In Vertical And Horizontal Soft Tissue Augmentation Be- fore Dental Implantation: A Randomized, Split-Mouth, Controlled Clinical Trial
}

Research Article

Zayed Alnuaimi ${ }^{1}$, Majd Othman ${ }^{2}$, Imad Katbeh ${ }^{3 *}$, Somia Naser ${ }^{4}$, Wilfrid Kamgang ${ }^{5}$, Olga Voeykova ${ }^{6}$, Mamasaidova Zarina ${ }^{7}$, SaidovaPatimat ${ }^{8}$

${ }^{1}$ MSc Student, Faculty of Dentistry, Department of Periodontology, Damascus University, Syria.

${ }^{2}$ Professor, Faculty of Dentistry, Department of Periodontology, Damascus University, Syria.

${ }^{3}$ Assistant Professor, Department of Pediatric Dentistry and Orthodontics RUDN University (Peoples' Friendship University of Russia). Russia, Moscow.

${ }^{4}$ MSc, Faculty of Dentistry, Department of Periodontology, Damascus University, Syria.

${ }^{5} \mathrm{PhD}$ student, Department of Pediatric Dentistry and Orthodontics. RUDN University, Russia.

${ }^{6} \mathrm{PhD}$ student, Department of Pediatric Dentistry and Orthodontics RUDN University, Russia.

${ }^{7}$ Medical Institute, Peoples' Friendship University of Russia (RUDN University) Moscow, Russia.

${ }^{8}$ Medical Institute.Peoples' Friendship University of Russia (RUDN University) Moscow, Russia.

\section{Abstract}

The presence of a sufficient amount of keratinized tissue around dental implants is directly related to their success, facilitates the following restorative procedures, and obtains satisfactory cosmetic results.

This study aims to investigate the effectiveness and predictability of different treatment modalities to gain keratinized tissue $(\mathrm{KT})$ in partial edentulous jaws prior to dental implant placement; modified free gingival graft (MFGG), and connective tissue graft (CTG).

Materials and Methods: A total of 14 (age range between 25 and 58 years) partially edentulous patients (28 sites) with insufficient zones of keratinized tissue at the prospective implant positionswere included in this study, two treatment modalities were performed in the lower jaw: MFGG, and CTG.

MFGG and CTG were applied in the premolar and molar positions randomly. Assessed outcomes up to 6 months postsurgery included changes in width and thickness of keratinized tissue.

Results: After 6 months of follow-up,changes in keratinized tissue width demonstrated an increase of $2.29 \pm 1.6 \mathrm{~mm}$ in connective tissue graft, whereas modified free gingival graft showed an increase of $3.95 \pm 1.25 \mathrm{~mm}$, on the other hand changes in keratinized tissue thickness demonstrated an increase of $0.85 \pm 0.5 \mathrm{~mm}$ in connective tissue graft, whereas modified free gingival graft showed an increase of $0.71 \pm 0.4 \mathrm{~mm}$.

Conclusion: The two methods were suitable to increase the width and thickness of KT over a 6-month period, although CTG alone rendered roughly 34\% less gain at KT width compared to MFGG.

Keywords: Modified Free Gingival Graft; Augmentation; Keratinized Tissue; De-Epithelialization; Keratinized Gingiva; Connective Tissue Graft.

\section{Introduction}

The absence of an adequate amount of keratinized mucosa is directly associated with inflammatory gingival manifestations, bleeding on probing, and bacterial plaque aggregation, in addition to poor cosmetic appearance [1-3].

Previous studies concluded that dental implants placed within sites with a minimum amount of keratinized tissues $(<2 \mathrm{~mm})$ are more susceptible to inflammatory manifestations and the accu-

\section{*Corresponding Author:}

Imad Katbeh,

Assistant Professor, Department of pediatric dentistry and orthodontics, Peoples’ Friendship University of Russia (RUDN University), 117198 Miklukho-Maklava Street 6, Moscow, Russia.

Tel: +79168268962

E-mail: katbeh@bk.ru

Received: October 01, 2021

Accepted: November 10, 2021

Published: November 15,202

Citation: Zayed Alnuaimi, Majd Othman, Imad Katbeh, Somia Naser, Wilfrid Kamgang, Olga Voeykova e al., A Modified Free Gingival Graft Technique In Vertical And Horizontal Soft Tissue Augmentation Before Dental Implantation: A Randomized, Split-Mouth, Controlled Clinical Trial. Int J Dentistry Oral Sci. 2021;8(11):5017-5022. doi: http://dx.doi.org/10.19070/2377-8075-210001011

Copyright: Imad Katbeh 2021 . This is an open-access article distributed under the terms of the Creative Commons Attribution License, which permits unrestricted use, distribution and reproduction in any medium, provided the original author and source are credited. 
mulation of bacterial plaque compared to dental implants placed within sites with sufficient keratinized tissues $(\mathrm{KT}>2 \mathrm{~mm})[4]$. Moreover, the presence of sufficient vertical thickness of soft tissue around the implants prevents the occurrence of resorption of the crestal bone, which can be witnessed with the presence of thin mucous around the implants [5]. Therefore, careful management of the soft tissues around the implants is an important and essential factor for obtaining satisfactory aesthetic and functional results in the long term [6].

Several previous studies have shown that the presence of a sufficient amount of keratinized tissue around dental implants is directly related to the success of the osseointegrated of dental implants, which facilitates the following restorative procedures and obtains satisfactory cosmetic results, and also allows maintaining the health of the tissues around the implants $[3,7]$.

Many different and useful surgical techniques are used to improve soft tissues, including pedicle flaps and soft tissue grafts [6].

From the beginning of the second half of the last century [1] free gingival grafts were the main technique to increase both the width of the keratinized tissue and the vestibular extension. That indicates the reliability of this clinical procedure $[2,3,7-10]$.

The aim of the present study was, therefore, to evaluate two treatment modalities, modified free gingival graft (MFGG), and connective tissue graft (CTG), to gain vertical and horizontal soft-tissue growth in the posterior region of the mandible before installation of a dental implant. In addition, to report outcomes 6 months following the surgical interventions.

\section{Materials And Methods}

\section{Trial design}

The present study was designed as a split-mouth randomized controlled trial to evaluate two procedures for the gain of keratinized tissue over a 6 -month period after the surgical interventions.

The study protocol was approved by the scientific research and postgraduate board ethics committee of Damascus University, Damascus, Syria (protocol code 3516 and date of approval 8 July 2019). The patients and parents were blinded by not being provided any information about the treatment group to which they were allocated.

\section{Study population and inclusion criteria}

Patients meeting the following inclusion criteria were consecutively recruited and enrolled at the Clinic of Periodontology, University of Damascus, Syria, between 2019 and 2021:

- Signed informed consent.

- The patient (male or female) must be 18 years or older.

- The patient is able to comply with the study-related procedures such as exercising good oral hygiene and attending all follow-up procedures.

- The patient can fully understand the nature of the proposed surgery and is able to provide a signed informed consent.

- Partial edentulous patients in need of implant therapy in the mandible and ability to place dental implants in the premolar and molar positions.

- A reduced width of keratinized tissue $(<2 \mathrm{~mm})$, measured from the center of the two prospective mandibular implant positions to the buccal mucogingival junction.

- A reduced thickness of keratinized tissue $(<2 \mathrm{~mm})$, measured at the center of the two prospective mandibular implant positions.

- Well-fitted, new maxillary and mandibular prostheses.

- Generally healthy.

- Commitment to maintaining good oral hygiene.

- No systemic disease that could affect wound healing and prevent implant placement.

\section{Exclusion criteria for all subjects included the following}

- Patient is a heavy smoker ( $>10$ cigarettes per day).

- Patient is an insulin-dependent diabetes.

- General contraindications for dental and/or surgical treatment are present.

- The patient has a history of malignancy, radiotherapy, or chemotherapy for malignancy within the past 5 years.

- The patient is pregnant or nursing.

- The patient is taking medications or having treatments, which have an effect on mucosal healing in general (e.g. Steroids, large doses of anti-inflammatory drugs).

- The patient has a disease, which affects connective tissue metabolism (e.g., collagenases).

- The patient is allergic to collagen.

- Patients having participated in a clinical trial within the last 6 months.

Patients not meeting all inclusion criteria were excluded from the study. Upon enrollment, alginate impressions of the mandible were obtained and stents for measurements were designed and fabricated at the laboratory.

The stent was designed in such a way that it allowed measuring the thickness of keratinized tissue at the center of the prospective implant positions and measuring the width of keratinized tissue from the center of the prospective implant positions to the buccal mucogingival junction.

\section{Randomization and Blinding}

The clinically studied sample was randomly distributed using a lottery, where the numbers from one to fourteen were written on paper cards representing the research cases according to the chronological sequence of their completion (No. 1 represents the first case to be treated ... and so on) and then they were randomly divided into two groups:

Group A (represents the group in which the right side was treated with Modified free gingival graft).

Group B (represents the group in which the left side was treated with the Connective tissue graft). The numbers shown in table (1) carry the results of randomization of the study sample.

A double blinding was also adopted in this study so that both the patient and the examiner were not know about the applied method.

\section{Surgical intervention}


At the day of surgery, patients rinsed with $0.2 \%$ of chlorhexidine solution and were given medication for pain relief (Mefenamic acid, $500 \mathrm{mg}$ ). Subsequently, photographs of the two sites were taken, the thickness of keratinized tissue was measured at the center of the two prospective implant positions using a periodontal probe and the prepared stent and the width of keratinized tissue was measured on the buccal side of the two prospective implant positions using a caliper and the prepared stent.

Following local anesthesia, two treatment modalities were then randomly applied to the left and right side of the mandible:

In-group MFGG After an aseptic and antiseptic procedure, the patient was anesthetized locally with articaine 4\% 1:100.000 (Nova DFL, Rio de Janeiro, Brazil). A horizontal incision was made under the bony crest of the edentulous space just below the mucogingival line. Two vertical incisions of approximately 4 $\mathrm{mm}$ were made, one in the mesial and one in the distal area of the edentulous space. The incision began in the mucogingival line toward the bottom of the vestibular mucosa, with the aid of a 15C scalpel blade. The papilla was preserved. A full thickness flap was made on the bony crest toward the lingual mucosa. Care was taken to avoid perforation and to maintain a free space between the mucosa and the bony crest. A partial thickness, $7 \mathrm{~mm}$ flap was made on the vestibular mucosa.

The free gingival graft was removed from the palate region between $2.0 \mathrm{~mm}-3.0 \mathrm{~mm}$ thickness and $10.0 \mathrm{~mm}$ of length. Before placement in the recipient bed, one part of graft was cascaded, (epithelial tissue was removed) is the modification of the classical technique of free gingival grafting [Figure 1]. The graft was positioned to cover the entire surgical area. The bony crest portion of the de-epithelialized graft was enveloped with the aid of a horizontal mattress suture under the flap. Compression sutures were made to stabilize the graft on the vestibular region of mandible. In-group CTG the same bed preparation procedures were performed in MFGG group except for preserving the mucosa resulting from lifting the partially thickened vestibular flap to cover the connective tissue graft.

The connective tissue graft was removed from the region in simi- lar measurement of MFGG and placed in the recipient bed in a manner similar to the MFGG in addition to covering the CTG with vestibular mucous.

Patients were given medications for pain relief (Mefenamic acid, $500 \mathrm{mg}$ every $8 \mathrm{~h}$ ), as well as a disinfectant solution (chlorhexidine digluconate, $0.2 \%$ solution for rinsing every $8 \mathrm{~h}$ for a period of 7 days). No adaptations were made to the mandibular prostheses and patients were not allowed to wear them during the entire study period. On day 7 post-surgery, all patients were recalled for suture removal, clinical measurements, and clinical photographs.

\section{Outcome measures}

The width (WKM) and thickness (TKM) of the keratinized mucosa were the clinical parameters assessed for the included subjects. WKM was measured on the buccal aspect tissue from the center of the prospective implant positions to the mucogingival junction positions using a caliper and the prepared stent. The TKM was measured at the center of the prospective implant positions using a UNC-15 probe (Hu-Friedy, USA). The parameters were assessed prior to surgical procedure (baseline), 4 weeks, 12 weeks and 6 months after surgery [Figure2, Figure3].

\section{Statistical analysis}

The recorded data was tabulated in Microsoft Excel (MS office version 2010). Data analysis was done using the Windows PC based software "MedCalc Statistical Software" version 13.3.1 (MedCalc Software bvba, Ostend, Belgium; http://www.medcalc. org; 2014). All testing was done at alpha 0.05 (95\% confidence limits). Intra- and inter-group comparison was performed using the Wilcoxcon and Mann-Whitney U, respectively. Differences above the $95 \%$ confidence intervals were regarded as statistically significant.

\section{Results}

Fourteen partially edentulous patients (28 sites) with an age range between 25 and 58 years (mean 41.5 years) were included in the study and underwent soft-tissue augmentation surgeries. All pa-

Figure 1. De-epithelialization of free gingival graft.

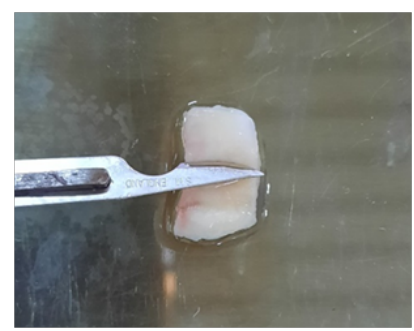

Figure 2. Occlusal view of the keratinized gingiva (a) before the surgical procedure and (b) after 6 months of MFGG application.

(a)
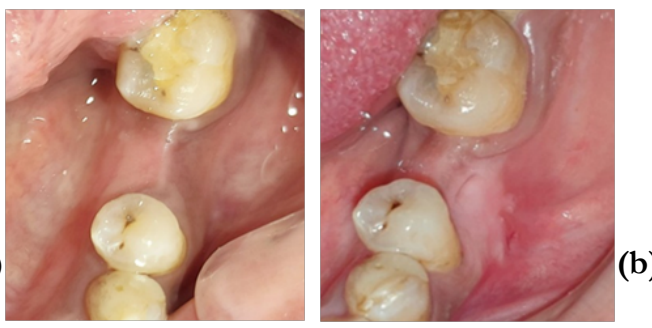
Figure 3. Occlusal view of the keratinized gingiva (a) before the surgical procedure and (b) after 6 months of CTG Application.

(a)

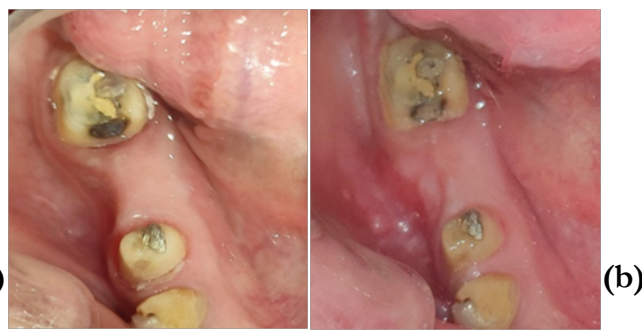

Table 1. Randomization results for study sample.

\begin{tabular}{|c|c|}
\hline Group A & Group B \\
\hline modified free gingival graft (MFGG) & Connective tissue graft(CTG) \\
\hline 2-4-5-8-10-11-13 & 1-3-6-7-9-12-14 \\
\hline
\end{tabular}

Table 2. Width of keratinized tissue in both studied groups through the experimental period.

\begin{tabular}{|c|c|c|c|c|c|c|c|}
\hline \multicolumn{7}{|c|}{ descriptive analysis } & \multirow{2}{*}{$\begin{array}{l}\text { Study of the existence of a } \\
\text { significant difference between } \\
\text { the pre-treatment and the last } \\
\text { time (after } 6 \text { months) } \\
\text { P-value }\end{array}$} \\
\hline & & number & Mean & Minimum value & Maximum value & SD & \\
\hline \multirow{4}{*}{$\begin{array}{c}\text { GroupM- } \\
\text { FGG }\end{array}$} & Baseline & 14 & 1.07 & 0 & 1.9 & 0.62 & \multirow{4}{*}{$\mathrm{P}=0.027$} \\
\hline & 1 Month & 14 & 5.59 & 4.9 & 7 & 0.69 & \\
\hline & 3 Months & 14 & 5.15 & 4.5 & 6.7 & 0.71 & \\
\hline & 6 Months & 14 & 5.02 & 4.4 & 6.5 & 0.68 & \\
\hline \multirow{4}{*}{$\begin{array}{l}\text { Group } \\
\text { CTG }\end{array}$} & Baseline & 14 & 1.04 & 0 & 2 & 0.56 & \multirow{4}{*}{$\mathrm{P}=0.007$} \\
\hline & 1 Month & 14 & 3.76 & 3 & 5 & 0.65 & \\
\hline & 3 Months & 14 & 3.26 & 2 & 4.4 & 0.7 & \\
\hline & 6 Months & 14 & 3.33 & 2 & 4.5 & 0.7 & \\
\hline
\end{tabular}

Table 3. Thickness of keratinized tissue in both studied groups through the experimental period.

\begin{tabular}{|c|c|c|c|c|c|c|c|}
\hline \multicolumn{7}{|c|}{ descriptive analysis } & $\begin{array}{l}\text { Study of the existence of a } \\
\text { significant difference between } \\
\text { the pre-treatment and the last } \\
\text { time (after } 6 \text { months) }\end{array}$ \\
\hline & & number & Mean & Minimum value & Maximumvalue & SD & P-value \\
\hline \multirow{4}{*}{$\begin{array}{c}\text { GroupM- } \\
\text { FGG }\end{array}$} & Baseline & 14 & 1.59 & 1 & 2 & 0.26 & \multirow{4}{*}{$\mathrm{P}=0.004$} \\
\hline & 1 Month & 14 & 2.66 & 2 & 3 & 0.36 & \\
\hline & 3 Months & 14 & 2.31 & 1.7 & 3 & 0.37 & \\
\hline & 6 Months & 14 & 2.3 & 2 & 2.8 & 0.27 & \\
\hline \multirow{4}{*}{$\begin{array}{l}\text { Group } \\
\text { CTG }\end{array}$} & Baseline & 14 & 1.58 & 1 & 2 & 0.28 & \multirow{4}{*}{$\mathrm{P}=0.001$} \\
\hline & 1 Month & 14 & 2.75 & 2 & 3.5 & 0.37 & \\
\hline & 3 Months & 14 & 2.44 & 2 & 3.3 & 0.4 & \\
\hline & 6 Months & 14 & 2.43 & 2 & 3 & 0.4 & \\
\hline
\end{tabular}

tients received two treatment modalities, healing was generally uneventful, and no local infection was observed at suture removal.

\section{Width of keratinized tissue}

At baseline, there was minimal WKM noted (group A, $1.07 \mathrm{~mm}$ $\pm 0.62 \mathrm{~mm}$; group $\mathrm{B}, 1.04 \mathrm{~mm} \pm 0.56 \mathrm{~mm})(\mathrm{p}=0.76)$. At 4 weeks,
12 weeks, and 6 months after surgery, the WKM significantly increased for both the groups from baseline. The WKM at 4 weeks, 12 weeks and 6 months for group $A(5.59 \mathrm{~mm} \pm 0.69 \mathrm{~mm}$, $5.15 \mathrm{~mm} \pm 0.71 \mathrm{~mm}, 5.02 \mathrm{~mm} \pm 0.68 \mathrm{~mm})$ was significantly higher than group $\mathrm{B}(3.76 \mathrm{~mm} \pm 0.65 \mathrm{~mm}, 3.26 \mathrm{~mm} \pm 0.70 \mathrm{~mm}, 3.33 \mathrm{~mm} \pm$ $70 \mathrm{~mm})(\mathrm{p}<0.001)$ Table $(2)$. 


\section{Thickness of keratinized tissue}

The mean TKM at baseline was $1.59 \mathrm{~mm} \pm 0.26 \mathrm{~mm}$ for group A and $1.58 \mathrm{~mm} \pm 0.28 \mathrm{~mm}$ for group B ( $\mathrm{p}=0.94)$.

However, at 4 weeks, 12 weeks and 6 months, there was no statistically significant difference in TKM between group B $(2.75 \mathrm{~mm} \pm$ $0.37 \mathrm{~mm}, 2.44 \mathrm{~mm} \pm 0.40 \mathrm{~mm}, 2.43 \mathrm{~mm} \pm 0.40 \mathrm{~mm}$ ) and group A $(2.66 \mathrm{~mm} \pm 0.36 \mathrm{~mm}, 2.31 \mathrm{~mm} \pm 0.37 \mathrm{~mm}, 2.30 \mathrm{~mm} \pm 0.27$ $\mathrm{mm})(\mathrm{p}=0.61)(\mathrm{p}=0.49)(\mathrm{p}=0.44)$ respectively. Table (3).

\section{Discussion}

Procedures to increase the soft tissue dimensions around the implants can be applied during different stages of the dental implant process such as before implantation, during the bone grafting procedure, in conjunction with the implantation process, during the bone osseointegration stage, at the temporization phase, before the delivery of the final prosthesis or during the second surgical stage [11].

Free gingival graft has been used for many years, as a successful and predictable technique to increase the dimensions of the gingival keratinized tissues, which prevents the occurrence of problems at the level of soft and hard tissues after the rehabilitation of the mouth with dental implants [8-10].

However, this technique requires two surgical sites, which may cause pain, discomfort, and a sense of dissatisfaction by the patient, in addition to the difference in color and texture from the surrounding soft tissues and some shrinkage of the gingival graft, all that leads to unsatisfactory aesthetic results [8-10].

In this study, a modification was made to the free gingival graft technique to obtain soft tissue gain in both vertical and horizontal directions in the posterior region of the lower jaw before dental implantation.

With this modification, part of the gingival graft is de-epithelialized and enters the submucosa at the top of the bone crest to obtain a tissue gain in the vertical direction, and the other part is fixed on the vestibular flap to increase the width of the keratinized mucosa. This technique is superior to the traditional technique in that one part of the graft is placed on top of the bone crest, allowing a soft tissue gain in both the vertical and horizontal directions [12].

The presence of adequate width of the keratinized mucosa is important for the preservation of the gingival tissue, as many studies have reported that the thick keratinized mucosa provides better oral hygiene, which reduces the accumulation of plaque, bleeding, inflammation, and gingival recession $[2,4]$.

The presence of thickened mucosa in both the vertical and horizontal directions is very important in the process of dental implants. Where the thick mucosa helps prevent early resorption of the crest bone and facilitate the process of placing dental implants, as it provides an increase in the stability of the area around the implants and allows the patient to maintain appropriate oral hygiene $[1,8,9]$.
The results of this study showed a significant improvement in the soft tissue thickness at the implant site, without a significant difference between the two study groups.

Both study groups recorded a statistically significant change in the soft tissue thickness index during the different measurement intervals.

These results are consistent with studies that recorded an increase in soft tissue volume after the use of a connective tissue graft at a rate ranging between $0.35-3.2 \mathrm{~mm}$, according to the site and the follow-up periods [13-15].

In both study groups, we noticed a slight change in tissue thickness between the first follow-up after a month of surgery and the last follow-up after 6 months, and this is because most of the changes occur in the gingival graft during the month of vaccination, and that is in agreement with Thoma D.S. et al. study [16].

While the results of soft tissue thickness assessment between the two groups showed no statistically significant difference after six months $(p=0.440)$ of surgery. The results of this study showed a significant improvement in the width of the attached gingiva at the implantation site, with a significant difference between the two groups.

Both study groups recorded a statistically significant change in the indicator of the width of the attached gingiva in different follow-up periods.

Studies have found an increase in the width of the keratinized gingiva after using a connective tissue graft placed under the slide in all forms of mucosal gingival surgery techniques [17-19].

As for the increase in the width of the keratinized tissue around the teeth or dental implants using a free gingival graft, it is documented in many studies [20-24].

Our results are in agreement with Thoma et al study [14] that compared different methods of tissue improvement around implants.

We also observed a change in the soft tissue width in the study groups between the first follow-up after one month of surgery and the last follow-up after 6 months, where the soft tissue width decreased in the modified free graft group after 6 months by 0.57 $\mathrm{mm}$ than after a month of follow-up and in the connective graft group, the width of the graft decreased after 6 months by 0.43 $\mathrm{mm}$. This is due to the shrinkage of the grafts that occurred during their maturation, full recovery (shrinkage), as the phenomenon of graft shrinkage occurs during the healing process despite being placed on an exposed bone, fixing it well and covering the connective grafts with full-thickness slices $[12,17,18]$. The thickness was similar in both groups andshowed no statistically significant difference after six months $(\mathrm{p}=0.440)$ of surgery.

\section{Conclusion}

Within the limitations of the study, it was noted that the modified free gingival graft technique increased the width of the keratinized mucosa before dental implantation over the observation period 
of 6 months, on the other handconnective tissue graft alone rendered roughly $34 \%$ less gain at keratinized tissue width compared to modified free gingival graft. At the same time, it increased the thickness of keratinized mucosa asmuch as the subepithelial connective tissue graftdid.

\section{References}

[1]. Bjorn H. Free transplantation of gingival propria. Odontol Revy. 1963; 14: 323.

[2]. Narayan SJ, Singh PK, Mohammed S, Patel RK. Enhancing the zone of keratinized tissue around implants. J Indian Prosthodont Soc. 2015 Apr-Jun; 15(2):183-6. PMID: 26929509.

[3]. Souza AB, Tormena M, Matarazzo F, Araújo MG. The influence of periimplant keratinized mucosa on brushing discomfort and peri-implant tissue health. Clin Oral Implants Res. 2016 Jun; 27(6): 650-5. PMID: 26474541.

[4]. Gobbato L, Avila-Ortiz G, Sohrabi K, Wang CW, Karimbux N. The effect of keratinized mucosa width on peri-implant health: a systematic review. Int J Oral Maxillofac Implants. 2013 Nov-Dec; 28(6): 1536-45. PMID: 24278922.

[5]. Linkevicius T, Apse P, Grybauskas S, Puisys A. Influence of thin mucosal tissues on crestal bone stability around implants with platform switching: a 1-year pilot study. J Oral Maxillofac Surg. 2010 Sep; 68(9): 2272-7. PMID: 20605308.

[6]. Cairo F, Pagliaro U, Nieri M. Soft tissue management at implant sites. J Clin Periodontol. 2008 Sep; 35(8 Suppl):163-7. PMID: 18724848.

[7]. Bouri A, Bissada N, Al-Zahrani MS, Faddoul F, Nouneh I. Width of keratinized gingiva and the health status of the supporting tissues around dental implants. Int J Oral Maxillofac Implants. 2008 Mar-Apr; 23(2): 323-6. PMID: 18548930.

[8]. Oh SL, Masri RM, Williams DA, Ji C, Romberg E. Free gingival grafts for implants exhibiting lack of keratinized mucosa: a prospective controlled randomized clinical study. J Clin Periodontol. 2017 Feb; 44(2): 195-203. PMID: 27930813

[9]. Marin DO, Leite AR, Nícoli LG, Marcantonio C, Compagnoni MA, Marcantonio E. Free Gingival Graft to Increase Keratinized Mucosa after Placing of Mandibular Fixed Implant-Supported Prosthesis. Case Rep Dent. 2017; 2017: 5796768. PMID: 28293441.

[10]. Agarwal C, Tarun Kumar AB, Mehta DS. Comparative evaluation of free gingival graft and AlloDerm $\left(^{\circ}\right)$ in enhancing the width of attached gingival: A clinical study. Contemp Clin Dent. 2015 Oct-Dec; 6(4): 483-8. PMID: 26681852.

[11]. Thoma DS, Benić GI, Zwahlen M, Hämmerle CH, Jung RE. A systematic review assessing soft tissue augmentation techniques. Clin Oral Implants Res. 2009 Sep; 20 Suppl 4: 146-65. PMID: 19663961

[12]. Imano MH, Cunha EJ, Storrer CLM, Deliberador TM. A modified free gingival graft technique for gaining vertical and horizontal soft tissue augmentation. J Indian Soc Periodontol. 2019 Jan-Feb; 23(1): 77-80. PMID:
30692749.

[13]. Eghbali A, De Bruyn H, Cosyn J, Kerckaert I, Van Hoof T. Ultrasonic Assessment of Mucosal Thickness around Implants: Validity, Reproducibility, and Stability of Connective Tissue Grafts at the Buccal Aspect. Clin Implant Dent Relat Res. 2016 Feb; 18(1): 51-61. PMID: 25040828.

[14]. Thoma DS, Buranawat B, Hämmerle CH, Held U, Jung RE. Efficacy of soft tissue augmentation around dental implants and in partially edentulous areas: a systematic review. J Clin Periodontol. 2014 Apr; 41 Suppl 15: S7791. PMID: 24641003.

[15]. Simion M, Rocchietta I, Fontana F, Dellavia C. Evaluation of a resorbable collagen matrix infused with rhPDGF-BB in peri-implant soft tissue augmentation: a preliminary report with 3.5 years of observation. International Journal of Periodontics and Restorative Dentistry. 2012 Jun 1; 32(3): 273.

[16]. Thoma DS, Zeltner M, Hilbe M, Hämmerle CH, Hüsler J, Jung RE. Randomized controlled clinical study evaluating effectiveness and safety of a volume-stable collagen matrix compared to autogenous connective tissue grafts for soft tissue augmentation at implant sites. J Clin Periodontol. 2016 Oct: 43(10): 874-85. PMID: 27310522.

[17]. Schmitt CM, Brückbauer P, Schlegel KA, Buchbender M, Adler W, Matta RE. Volumetric soft tissue alterations in the early healing phase after peri-implant soft tissue contour augmentation with a porcine collagen matrix versus the autologous connective tissue graft: A controlled clinical trial. Journal of Clinical Periodontology. 2021 Jan; 48(1): 146-63.

[18]. Aroca S, Molnár B, Windisch P, Gera I, Salvi GE, Nikolidakis D, et al. Treatment of multiple adjacent Miller class I and II gingival recessions with a Modified Coronally Advanced Tunnel (MCAT) technique and a collagen matrix or palatal connective tissue graft: a randomized, controlled clinical trial. Journal of clinical periodontology. $2013 \mathrm{Jul}$; 40(7): 713-20.

[19]. Tözüm TF, Dini FM. Treatment of adjacent gingival recessions with subepithelial connective tissue grafts and the modified tunnel technique. Quintessence Int. 2003 Jan; 34(1): 7-13. PMID: 12674352.

[20]. Raoofi S, Asadinejad SM, Khorshidi H. Evaluation of Color and Width of Attached Gingiva Gain in Two Surgical Techniques: Free Gingival Graft and Connective Tissue Graft Covered By Thin Mucosal Flap, a Clinical Trial. J Dent (Shiraz). 2019 Dec; 20(4): 224-231. PMID: 31875168.

[21]. Happe A, Stimmelmayr M, Schlee M, Rothamel D. Surgical management of peri-implant soft tissue color mismatch caused by shine-through effects of restorative materials: one-year follow-up. Int J Periodontics Restorative Dent. 2013 Jan-Feb; 33(1): 81-8. PMID: 23342350

[22]. Moses O, Artzi Z, Sculean A, Tal H, Kozlovsky A, Romanos GE, et al. Comparative study of two root coverage procedures: a 24-month follow-up multicenter study. J Periodontol. 2006 Feb; 77(2): 195-202. PMID: 16460244.

[23]. Nemcovsky CE, Artzi Z, Tal H, Kozlovsky A, Moses O. A multicenter comparative study of two root coverage procedures: coronally advanced flap with addition of enamel matrix proteins and subpedicle connective tissue graft. J Periodontol. 2004 Apr; 75(4): 600-7. PMID: 15152826.

[24]. da Silva RC, Joly JC, de Lima AF, Tatakis DN. Root coverage using the coronally positioned flap with or without a subepithelial connective tissue graft. J Periodontol. 2004 Mar; 75(3): 413-9. PMID: 15088880. 